\title{
Oligomerization of phenothiazin-5-ium tetraiodide in the presence of bases
}

\author{
(C) Alena I. Khadieva, Vladimir V. Gorbachuk, and Ivan I. Stoikov** \\ Department of Organic Chemistry. A.M. Butlerov Institute of Chemistry. Kazan Federal University. \\ Kremlevskaya St., 18. Kazan, 420008. Tatarstan Republic. Russia. \\ Phone:+7 (843)233-74-62.E-mail: ivan.stoikov@mail.ru
}

*Supervising author; ${ }^{+}$Corresponding author

Keywords: phenothiazine, phenothiazin-5-ium tetraiodide, triethylamine, oligomerization.

\begin{abstract}
Methylene blue and its structural analogs (phenothiazine derivatives) are well known photodynamically and photochemically active agents, which are used in modern medicine, biology, and industry due to their low toxicity, high absorption in the therapeutic window region $(600-660 \mathrm{~nm})$. Methylene blue being one of the most studied phenothiazine derivative is employed as an antibacterial agent and also as an antidote to cyanide, carbon monoxide and hydrogen sulfide. Phenothiazin-5-ium tetraiodide is one of the most convenient precursors for the synthesis of structural analogues of methylene blue among the variety of modern synthetic approaches. Nucleophilic addition of aromatic and aliphatic amines to phenothiazin-5-ium tetraiodide can be used to obtain a wide range of 3,7-phenothiazine-5-ium derivatives. The specificities of addition reactions of dialkylamines and aromatic amines to phenothiazin-5-ium tetraiodide are low yields and formation of difficultly separable mixtures of products. It was found that reactions of phenathiazin-5-ium tetraiodide with amines containing secondary and tertiary amino groups lead to oligomerization of phenathiazin-5-ium tetraiodide (3,10-positions). Basicity of tertiary amino group is crucial in oligomerization of phenathiazin-5ium tetraiodide. It is shown, that triethylamine use as a base allows to synthesize of oligo $(3,10)$ phenothiazines with high yields. According to ${ }^{1} \mathrm{H},{ }^{13} \mathrm{C}$ NMR, IR spectroscopy data and MALDI mass-spectrometry data, thereaction product is a mixture of oligomers, consisting mainly of three to four units.
\end{abstract}

\section{References}

[1] A. Khadieva, V. Gorbachuk, D. Shurpik, I. Stoikov. Synthesis of tris-pillar[5]arene and its association with phenothiazine dye: Colorimetric recognition of anions. Molecules. 2019. Vol.24(9). P.1807.

[2] A.I. Khadieva, V.V. Gorbachuk, G.A. Evtugyn, S.V. Belyakova, R.R. Latypov, S.V. Drobyshev, I.I. Stoikov. Phenyliminophenothiazine based self-organization of polyaniline nanowires and application as redox probe in electrochemical sensors. Sci. Rep. 2019. Vol.9(1). P.1-10.

[3] O. Yazdani, M. Irandoust, J.B. Ghasemi, S. Hooshmand. Thermodynamic study of the dimerization equilibrium of methylene blue, methylene green and thiazole orange at various surfactant concentrations and different ionic strengths and in mixed solvents by spectral titration and chemometric analysis. Dyes Pigm. 2012. Vol.92(3). P.1031-1041.

[4] N.M. Storozhok, T.K. Timokhina, Ya.I. Paromova, A.V. Voloshin. Photodynamic inactivation of microorganisms water treatment process. Butlerov Communications. 2017. Vol.51. No.7. P.149-157. DOI: $10.37952 /$ ROI-jbc-01/17-51-7-149

[5] L.M. Moreira, J.P. Lyon, A. Lima, L. Codognoto, D. Severino, M.D.S. Baptista, A.L. Tessaro, A.P. Gerola, N. Hioka, M.R. Rodrigues, J.A. Bonacin, S.D.C. Santos, A.P. Romani, H.P.M.D. Oliveira. The Methylene Blue Self-aggregation in Water/Organic Solvent Mixtures: Relationship Between Solvatochromic Properties and Singlet Oxygen Production. Orbital: Electron. J. Chem. 2017. Vol.9(4). P.279-289.

[6] B. Wilson, M.J. Fernández, A. Lorente, K.B. Grant. Synthesis and DNA interactions of a bisphenothiazinium photosensitizer. Org. Biomol. Chem. 2008. Vol.6(21). P.4026-4035.

[7] S.C. Nuñez, T.M. Yoshimura, M.S. Ribeiro, H.C. Junqueira, C. Maciel, M.D. Coutinho-Neto, M.S. Baptista. Urea enhances the photodynamic efficiency of methylene blue. J. Photochem. Photobiol. B. 2015. Vol.150. P.31-37. 
[8] M. Tiravia, F. Sabuzi, M. Cirulli, S. Pezzola, G. Di Carmine, D.O. Cicero, B. Floris, V. Conte, P. Galloni. 3, 7-Bis ( $N$-methyl- $N$-phenylamino) phenothiazinium Salt: Improved Synthesis and Aggregation Behavior in Solution. Eur. J. Org. Chem. 2019. Vol.20. P.3208-3216.

[9] L. Strekowski, D.F. Hou, R.L. Wydra, R.F. Schinazi. A synthetic route to 3-(dialkylamino) phenothiazin5-ium salts and 3, 7-disubstituted derivatives containing two different amino groups. J. Heterocycl. Chem. 1993. Vol.30(6). P.1693-1695.

[10] M. Wainwright, S.D. Brandt, A. Smith, A. Styles, K. Meegan, C. Loughran. Phenothiazinium photosensitisers VII: novel substituted asymmetric $N$-benzylphenothiaziniums as photoantimicrobial agents. J. Photochem. Photobiol. B. 2010. Vol.99(2). P.74-77.

[11] A.I. Khadieva, V.V. Gorbachuk, I.I. Stoikov. Synthesis and supramolecular self-assembly of phenothiazine functionalized by carboxyphenyl fragments. Russ. Chem. Bull. 2020. Vol.69. P.333-338.

[12] M. Wainwright, A. McLean. Rational design of phenothiazinium derivatives and photoantimicrobial drug discovery. Dyes Pigm. 2017. Vol.136. P.590-600.

[13] J.A. Cody, C.S. Larrabee, M.D. Clark, S. Hlynchuk, J.A. Tatum. A convenient one-pot synthesis of ethylene blue. Tetrahedron Lett. 2012. Vol.53(36). P.4896-4899.

[14] A.I. Khadieva, P.A. Gorbatova, V.V. Gorbachuk, R.R. Latypov, I.I. Stoikov. Morphology and structure of phenothiazine oligomers: Synthesis and effects of oxidants. AIP Conf. Proc. 2019. Vol.2064(1). P.030004.

[15] Y.M. Korolev, S.Z. Ozkan. Synthesis and X-Ray diffraction study of polyphenothiazine. Dokl. Phys. Chem. 2009. Vol.429(1). P.223.

[16] M.Y. Jo, S.S. Park, J.H. Kim. Synthesis, optical and electrochemical properties of in-situ thermally cross-linkable oligo (10H-alkylphenothiazine). Synth. Met. 2012. Vol.162(1-2). P.70-78.

[17] T. Okamoto, M. Kuratsu, M. Kozaki, K. Hirotsu, A. Ichimura, T. Matsushita, K. Okada. Remarkable structure deformation in phenothiazine trimer radical cation. Org. Lett. 2004. Vol.6(20). P.3493-3496. 